\title{
Recently Recognized Indigenous Cattle Breeds of India: A Review
}

\author{
K. B. Savalia ${ }^{1}$, A. R. Ahlawat ${ }^{2}$, V. V. Gamit ${ }^{3 *}$, S. S. Parikh ${ }^{4}$ and A. D. Verma ${ }^{2}$ \\ ${ }^{I}$ Veterinary officer, Polytechnic in Animal Husbandry, JAU, Junagadh, India \\ ${ }^{2}$ Department of Animal Genetics and Breeding, College of Veterinary Science and \\ A.H., J.A.U., Junagadh, India \\ ${ }^{3}$ Department of Livestock Production Management, College of Veterinary Science and A.H., \\ J.A.U., Junagadh, India \\ ${ }^{4}$ Cattle Breeding Farm, J.A.U., Junagadh, India \\ *Corresponding author
}

\section{A B S T R A C T}

\section{Keywords}

NBAGR, Zebu, Brisket, Breed, Hump

Article Info

Accepted:

04 November 2019

Available Online:

10 December 2019
India, third richest biodiversity countries in the Asia, and it is home to huge indigenous cattle genetic resources. India having 190.9 million cattle population with 43 register native indigenous cattle breeds, in addition to this large number of non-descript cattle population available throughout country. This indigenous cattle breeds are especially more adapted to different agro-climatic conditions of India and some of indigenous cattle breeds were performing excellent in other country throughout world. In recent times, several of the indigenous breeds suffered decline mainly due to their becoming uneconomical. Apart from this indigenous cattle breeds have merits like better disease resistance, low input management and better survival in extreme weather condition, this make them imperative in current climate change situation. Phenotypic characterization is vital for managing the animal genetic resources at nationwide and regional levels. Huge proportion of nondescript cattle characterization and inventorization of cattle genetic resources of India is still incomplete. National Bureau of Animal Genetic Resources (NBAGR) at Karnal by Indian Council of Agricultural Research (ICAR), is main functioning on identification, evaluation, characterization, conservation and sustainable Utilization of Livestock Genetic Resources. With efforts from NBAGR phenotypic characterization of domestic animal diversity of India, accelerated. A large number of recognized livestock and poultry breeds and populations were systematically studied and documented recently. This review provides information of the cattle breeds recently recognize by NBAGR, ICAR and population of cattle, phenotypic characterization and documentation in India.

\section{Introduction}

India is the seventh largest country in the world and is a mega-biodiversity centre (Srivastava et al., 2019). Over 70 per cent of its people are engaged in vocations connected with farming and animal husbandry. In India, total livestock population is 512.5 million and among that 190.9 million are cattle, which is cover 37.28 percent of total livestock 
population of the country (Anonymous, 2012). When we seeing global picture almost $30 \%$ of the world's cattle population of about 1.4 billion exist in in India (Robinson et al., 2014). India ranks first in milk production with 165.4 million tonnes of milk in 2016-17, out of those indigenous cattle contribute $11.3 \%$ and $9.5 \%$ by non-descriptive cattle (BAHS, 2017). Livestock breeds are recognized as significant components of world biodiversity because the genes and gene combinations they carry may be useful to agriculture in the future (Hall et al., 1995). Bosindicus cattle (Zebu cattle) were evolved over hundred years with very little scientific selection and majorly followed in Indian traditional animal husbandry practices, because of this zebu cattle were much more adapted to harsh local environment, resistance to tropical diseases and external parasites and sustenance on low quality roughages and grasses (Sharma et.al.2015). A diversified agro-ecological zones in India have helped to develop number of cattle populations. Breed characterization allows to study assessment of genetic variability, a fundamental element in working out breeding strategies and genetic conservation plans. There are forty three recognized breeds of cattle in India, in addition to large number of non-descript cattle. In recent times, several of the indigenous breeds suffered decline mainly due to their becoming uneconomical. India has large number of breeds with wide genetic diversity than other countries. The local breeds have many merits over exotic breeds viz. better disease resistance than exotic breeds, more suitable for low input management system, Survive better in local environmental condition, Suitable for draught work In addition, existence of superior indigenous breeds can provide valuable research inputs for developing superior breeds. It is therefore important that Indigenous breeds of cattle are conserved, developed and proliferated. Breed registration and recognition is a very important step for breed certification and all relevant information regarding the enormous and biodiverse animal genetic resources of our country the procedure shall lead to formation of breed inventory and try identify and understand these unique genetic resources which shall ultimately facilitate the genetic improvement of the native livestock population.

\section{Badri (Pahadi)}

Badri has become the first registered cattle breed of Uttarakhand which is certified by the National Bureau of Animal Genetic Resources (NBAGR). This breed is found in the hilly regions of Uttarakhand and balanced gait while walking. Badri cattle are small in size having long legs and varied body colours black, brown, red, white or grey. Straight forehead with prominent poll, medium to large hump. Udder is small and tucked up with the body. These are well adapted to the hilly terrain and climatic conditions and comparatively more resistant to diseases. Urine has better value due to their feeding habitat. The lactation milk yield ranges from 547 to $657 \mathrm{~kg}$ with an average milk fat of $4 \%$. Bangaet al., (2005) recorded the body measurements in Badri cattle for heart girth, height at wither and body length which averaged as 62.15 $\square 3.2,59.66 \square 2.5$ and $47.55 \square 1.5 \mathrm{~cm}$ in calves, $115 \square 6.4,89.71 \square$ 3.1 and $84.65 \square 2.6 \mathrm{~cm}$ in heifers and 137.63 $\square 7.1,100.76 \square 5.8,103.97 \square 6.3 \mathrm{~cm}$ in adults, respectively

\section{Belahi (Morni, Desi)}

Belahi cattle are spreaded in North Himalayan foothills with their breeding tract in North eastern parts of Haryana, Punjab and Himachal Pradesh (Vohra et al., 2012). They are migratory breed and well adapted to local environment and are excellent dual-purpose (milk and draught) cattle underneath extensive 
management system and provides livelihood security to Gujjar pastoralists of the region (Vohra et al., 2017). Body coat colour pattern having reddish brown and face, extremities and ventral part of body having different degrees of white colour. Head is straight and broad with prominent poll. Horns are sickle shaped, curved upwards and inwards. adult body weights were $304.8 \pm 1.35$ and $266.74 \pm$ $2.15 \mathrm{~kg}$ in males and females, respectively. Overall average daily milk yield and 305 day milk yield were estimated as $3.25 \pm 0.15 \mathrm{~kg}$ and $1014.43 \pm 45.46 \mathrm{~kg}$ respectively (Yadav et al., 2018). The lactation milk yield ranges from 182 to $2092 \mathrm{~kg}$ with an average milk fat of $5.2 \%$.

\section{Gangatiri (Eastern Hariana or Shahabadi)}

Gangatiri is dual-purpose zebu cattle breed, found mainly in Varanasi, Chandauli, Ghazipur and Ballia district of eastern Utter Pradesh and adjacent areas of Bihar state of India. Bhinchharel al. (2017) observed characteristic feature such as medium size muzzle, lustrous eyes, medium sized dewlap, small brisket, sharp and smooth shoulder with medium legs, medium sized bowl shaped udder with cylindrical shaped medium sized teats and prominent, crooked and branched milk veins as characteristic features of the Gangatiri cattle. Forehead is prominent, straight and broad with shallow groove in the middle. Developed mostly by small and marginal farmers of several communities like Yadav, Bhumihar, Brahmin, Rajbhar, Kshatriya, Patel, etc. Lactation length was 187.80 days, average dry period length was 176.60 days and average calving interval was 372.40 days in Gangatiri cattle (Singh el al., 2017). Milk yield ranges from 900 to $1200 \mathrm{~kg}$ per lactation with an average fat in milk is 4.9\%. Gangatiri cattle contributed considerably to total income of framers, so higher profit from rearing Gangatiri cattle will have significant positive impact on socio- personal and socio-economic status of these farmers reported by (Singh et al., 2018).

MalnadGidda (Gidda, Uradana, Varshagandhi)

The name of the breed, MalnadGidda, has been derived from in three words Malay means hilly, Nadu means place (Malay + $\mathrm{Nadu}=\mathrm{Malnad}$ ) and Gidda means small. As indicated in name this is a small size breed and found in hilly tract of Chikmagalur, Dakshina Kannada, Hassan, Kodagu, Uttar Kannada and Udupi District of Karnataka. There are 5 coat colours present in these animals (black, brown, red, fawn and white, sometimes mixture of any 2) but black colour is predominant (Singh et al., 2008). The animals bear a compact body weighing about 90 to $140 \mathrm{~kg}$. Singh et al., (2008) observed in his study that the colour of skin, eyelids, muzzle, tail switch were predominately black in the animals with black coat colour, however, the muzzle colour was carroty or pinkish in fawn and white coat coloured animals. The head profile was straight in all most all the female animals but it was slightly concave in males. The horns were of small to medium in length and outward, upward and inward with pointed tips in orientation. The limbs were short and comparatively thinner. The hump was small in cows but more prominent in bulls. The dewlap size was small to medium. The udder was bowl shaped and small in size. The teats were funnel shaped with pointed tips.

\section{Lakhimi}

Lakhimi cattle of Assam are distributed in entire state and reared for milk and draught purposes by local people. Total population is about 79 Lakhs. Animals are small sized, horned and have relatively short legs. Coat colour is variable mainly brown and grey. Hump is medium in size and the backline is 
slightly curved. Udder is small and bowel shaped. Bullocks are excellent draft animals especially for carting and ploughing especially in the muddy fields for paddy cultivation. Lactation milk yield ranges from 270 to 375 kg (ICAR-NBAGR Newsletter-2017). The milk yield ranges from 325 to $375 \mathrm{~kg}$ per lactation with an average $5.3 \%$ fat. Age at first calving ranges from 44 to 49 months (Table 1 and Fig. 1-7).

Table.1

\begin{tabular}{|c|c|c|c|}
\hline S.N. & Breed & Home Tract & Accession number \\
\hline $\mathbf{1}$ & Badri & Uttarakhand & INDIA_CATTLE_2400_BADRI_03040 \\
\hline $\mathbf{2}$ & Belahi & Haryana and Chandigarh & INDIA_CATTLE_0532_BELAHI_03038 \\
\hline $\mathbf{3}$ & Gangatiri & Uttar Pradesh and Bihar & INDIA_CATTLE_2003_GANGATIRI_03039 \\
\hline $\mathbf{4}$ & MalnadGidda & Karnataka & INDIA_CATTLE_0800_MALNADGIDDA_03037 \\
\hline $\mathbf{5}$ & Lakhimi & Assam & INDIA_CATTLE_0200_LAKHIMI_03041 \\
\hline $\mathbf{6}$ & Ladakhi & Jammu and Kashmir & INDIA_CATTLE_0700_LADAKHI_03042 \\
\hline $\mathbf{7}$ & Konkan Kapila & Maharashtra and Goa & INDIA_CATTLE_1135_KONKANKAPILA_03043 \\
\hline
\end{tabular}

Fig.1 Badri (Pahadi)

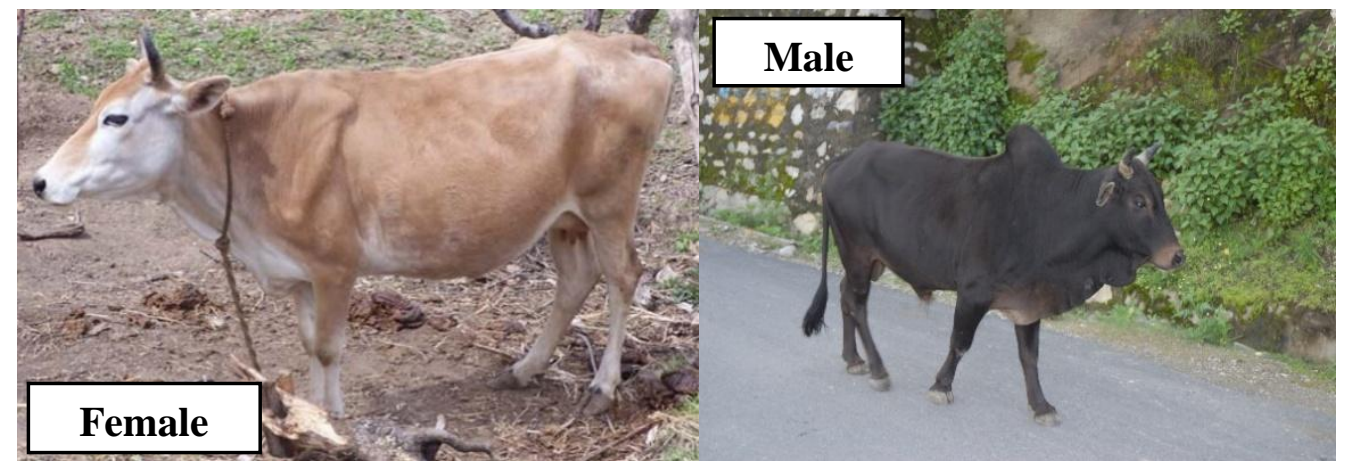

Fig.2 Belahi (Morni, Desi)

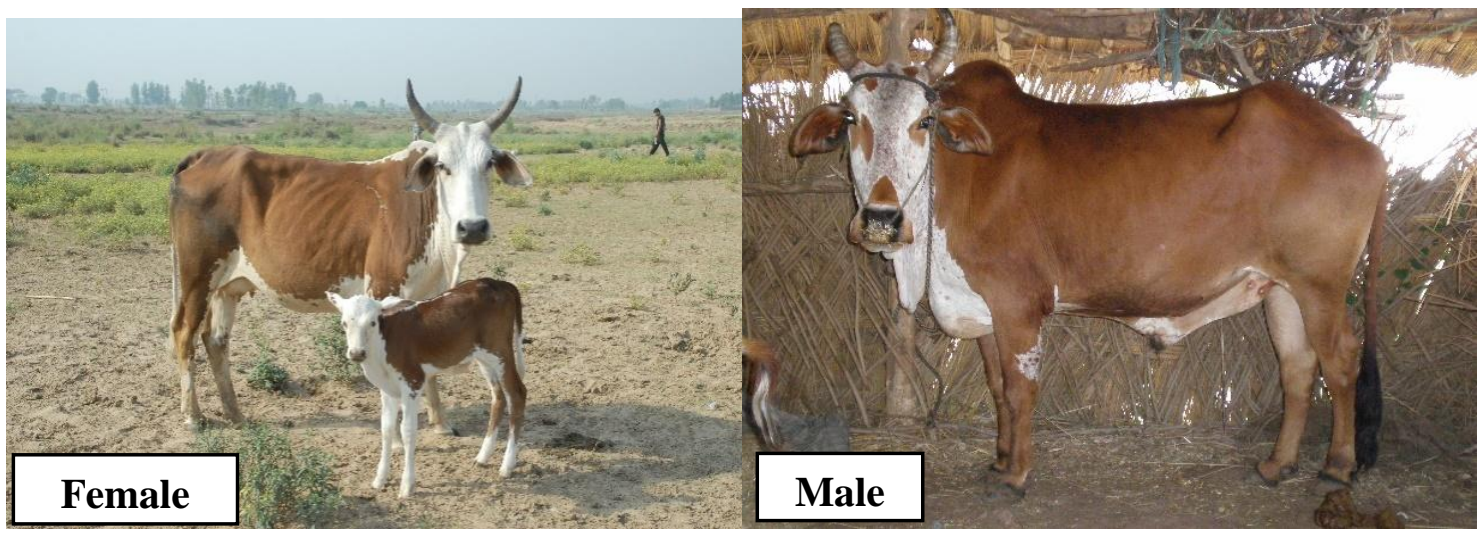


Fig.3 Gangatiri (Eastern Hariana or Shahabadi)

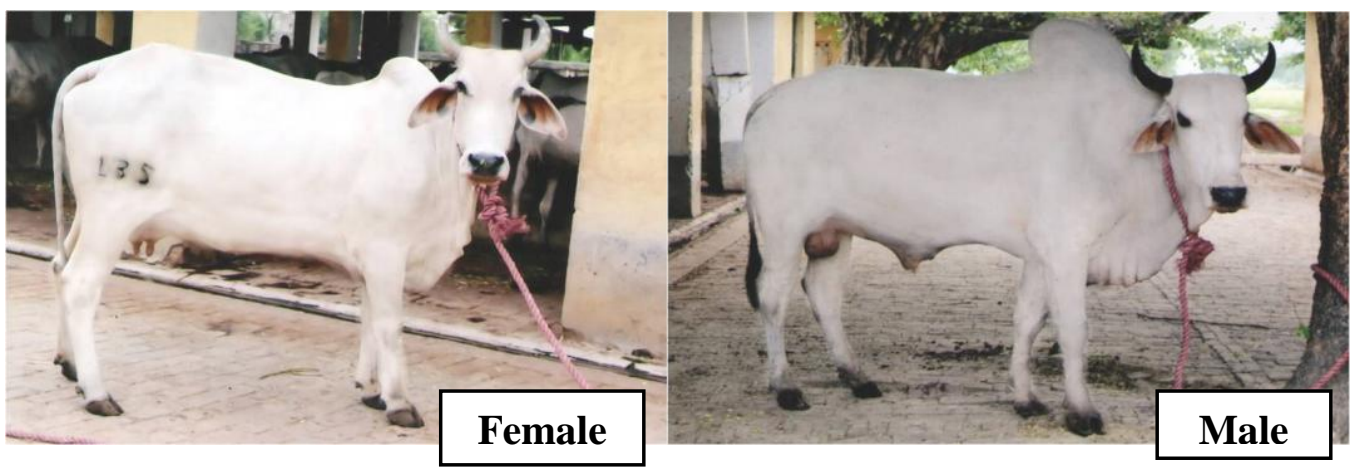

Fig.4 MalnadGidda (Gidda, Uradana, Varshagandhi)

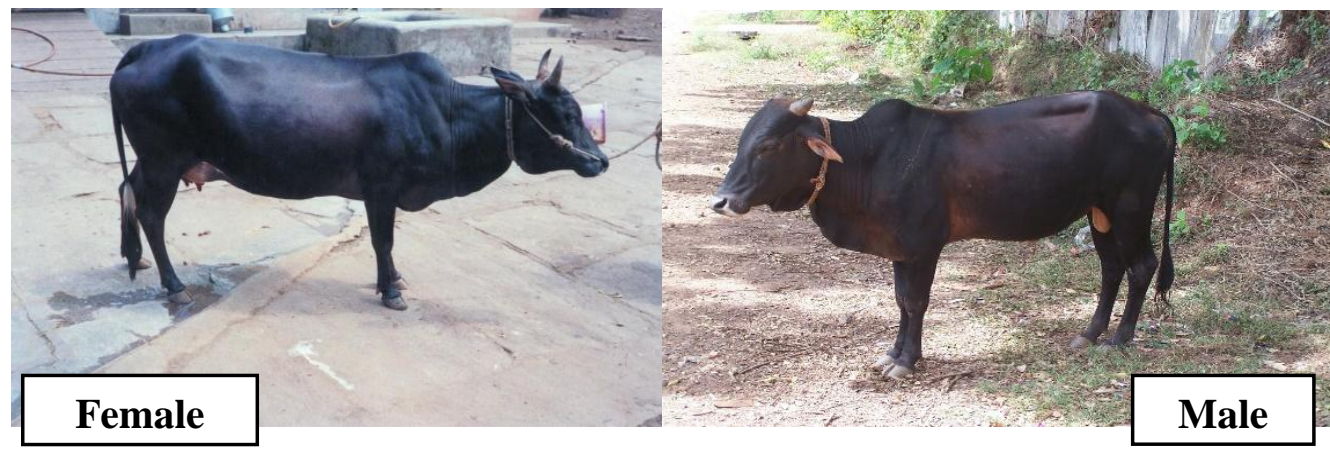

Fig.5 Lakhimi

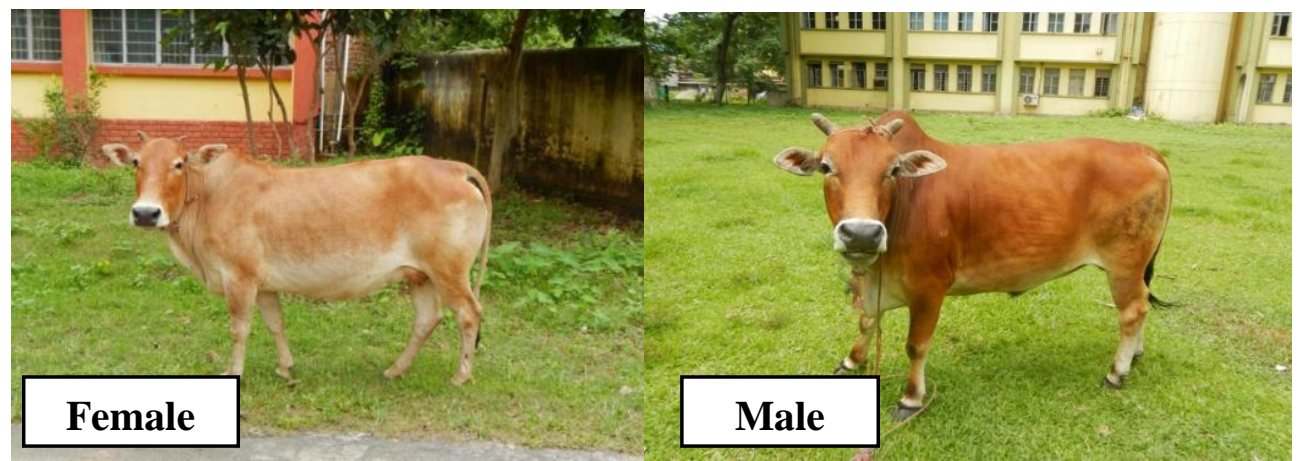

Fig.6 Ladakhi

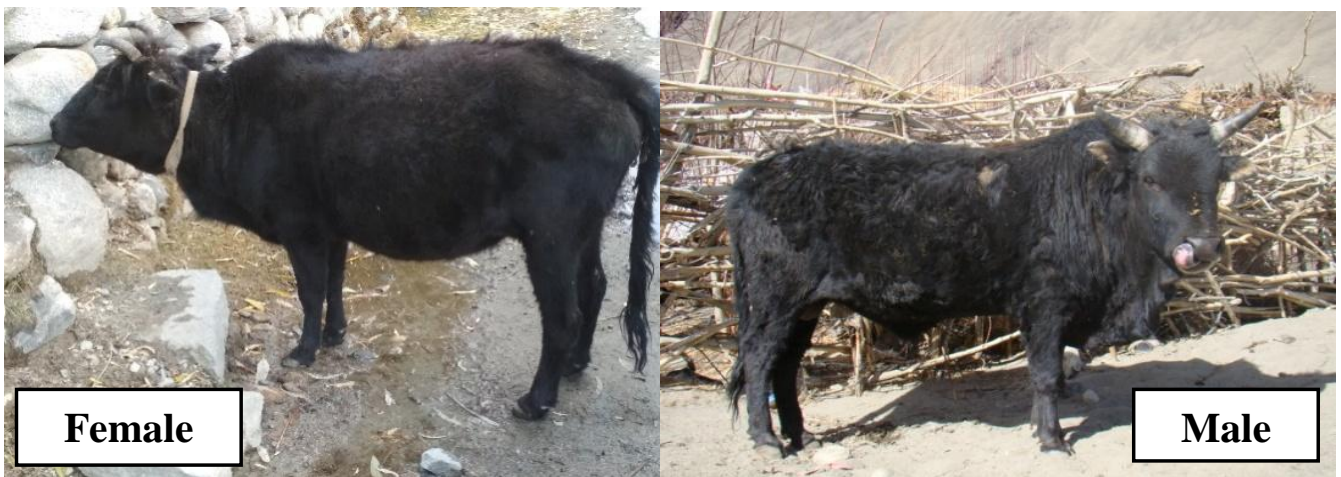


Fig.7 Konkan Kapila (Konkan gidda, Konkan)

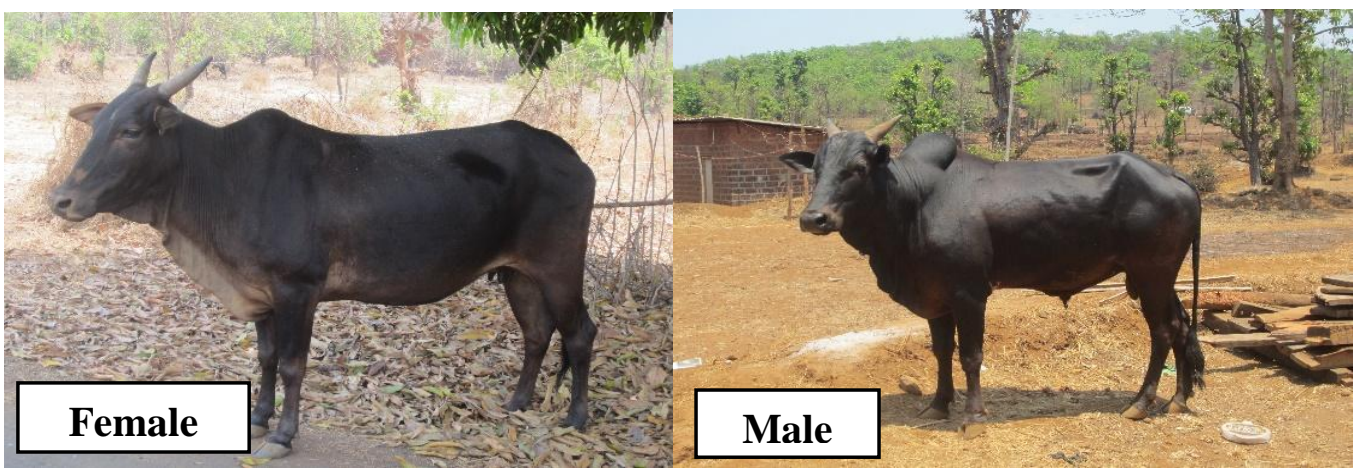

\section{Ladakhi}

Ladakhi cattle are native to Ladakh region of Jammu and Kashmir. These are small sized and short statured black or brown colored animals well adapted to extreme cold climatic and hypoxic conditions. Ladakhi cattle were small in size with cylindrical type of body. Animals were well built and compact with strong legs. Body colour varied in different colours and shades i.e. black, brown and black with white patches. Body had long hairs with glossy sheen. Colour of skin, muzzle, eyelids and hoof were black while horns were black in colour.

Horns curved upward, outward then forward orientation with pointed tips. Hump and dewlap were small. Head was small. Face was short and concave. Ears were small to moderate in length and horizontal in orientation. Size of udder was small not that much develop but milk vein were prominent. Tail was long, touching almost ground level. Animals were well docile with very low milk production.

Average daily milk yield range from 1.0 to 4.5 $\mathrm{kg}$ (Pundir. 2016). Udder is small in size and bowl shaped. Milk yield is around 2 to $5 \mathrm{~kg} /$ day. Milk has high fat percentage of around 5\% and used mainly for producing butter and churpi, important part of diet of local people (nbagr.res.in).
Konkan Kapila (Konkan gidda, Konkan)

The breeding tract of this breed includes Thane, Raigadh, Ratnagiri, Sindhudurg and Palghar districs of Maharashtra. Distributed in Konkan region of Maharashtra and Goa. The animals are of various coat colours, predominant being reddish brown/black, however white/grey, mixed and in few animals brown or fawn coat colour is also available. The animals are small to medium in size with compact body, straight face, small to medium sized hump and dewlap. Generally straight and small sized horn emerge from side of the poll behind and above eyes in outward and going upwards and backwards ending with pointed tips. Konkan Kapila cattle are low milk producers (around $2.25 \mathrm{~kg}$ /day) and possess good draft ability suited to hilly terrain and hot and humid climate of its native tract (nbagr.res.in).

Cattle species form a chief share of livestock in India with major share coming from it. Indigenous genetic resources in livestock sector and their conservation have thus become crucial for sustained food production.

The challenge is the conservation of livestock genetic resources and also increasing output per unit from livestock averting major loss in genetic diversity. ICAR-NBAGR, Karnal is the nodal government organization for registration of recognized germplasm in 
country. Newly identified breeds are approved by Breed Registration Committee of Indian Council of Agricultural Research (ICAR) headed by Deputy Director General (Animal Sciences).

\section{References}

Anonymous, 2012. 19th Livestock Census2012. All India Report. Department of Animal Husbandry, Dairying and Fisheries, Ministry of Agriculture and Farmers Welfare, GoI, New Delhi.

Banga, R. K., Kumar, P., Singhal, L. K., Sharma, A. and Chauhan, R. S. 2005. Red hill cattle is characterized as 'Badri cow' based on physical characters and body measurements. The Indian Cow: The Scientific and Economic Journal. 2(3): 10-14.

BAHS (2017) Basic Animal Husbandry and Fisheries Statistics 2017. Published by Department of Animal Husbandry, Dairying and Fisheries, Ministry of Agriculture and Farmers Welfare, Government of India, New Delhi

Bhinchhar, B. K., Paswan, V. K., Yadav, S. P.and Singh, P. 2017. Characterization of Gangatiri cattle breed in Gangatic plains of Eastern Uttar Pradesh, India. Indian Journal of Animal Research. 51(6):988992.

Hall, S. J. and Bradley, D. G. 1995. Conserving livestock breed biodiversity. Trends in ecology and evolution. 10(7): 267-270.

Pundir, R.K. 2016. Management of Cattle genetic resources of North Himalayan Region of India. In: Compendium of 13th Convention and Symposium of Society for Conservation of Domestic Animal Biodiversity. Jammu, India, pp. 32-42.

Robinson, T.P., Wint, G.W., Conchedda, G., Van Boeckel, T.P., Ercoli, V., Palamara, E., Cinardi, G., D'Aietti, L., Hay, S.I. and Gilbert, M., 2014. Mapping the global distribution of livestock. PloS one, 9(5): e96084

Sharma, R., Kishore, A., Mukesh, M., Ahlawat, S., Maitra, A., Pandey, A. K. and Tantia, M. S. 2015. Genetic diversity and relationship of Indian cattle inferred from microsatellite and mitochondrial DNA markers. BMC genetics. 16(1), 73.

Singh, P. K., Pundir, R. K., Manjunath, V. K., Rudresh, B. H. and Govindaiah, M. G. 2008. Features and status of miniature indigenous germplasm of cattle- Malnad Gidda. Indian Journal of Animal Sciences. 78(10): 1123-1126.

Singh, P. K., Sankhala, G. and Singh, P. K. 2017. Performance of Gangatiri cattle rearing in field conditions. International Journal of Livestock Research. 7(3):142148.

Singh, P. K., Sankhala, G., and Singh, P. K. 2018. Perception of dairy farmers about Gangatiri cattle rearing in eastern Uttar Pradesh. Indian Journal of Dairy Science, 71(5), 496-501.

Srivastava, A. K., Patel, J. B., Ankuya, K. J., Chauhan, H. D., Pawar, M. M. and Gupta, J. P. 2019. Conservation of Indigenous Cattle Breeds. Journal of Animal Research, 9(1), 1-12.

Vohra, V., Niranjan, S.K. and Joshi, B. K. 2012.Belahi cattle: uniform but distinct germplasm of Haryana. Journal of Animal Research: 2(1):47-51.

Vohra, V., Sodhi, M., Niranjan, S. K., Mishra, A. K., Chopra, A., Kumar, M., and Joshi, B. K. 2017. Characterization of rare migratory cattle and evaluation of its phylogeny using short-tandem-repeatbased markers. Journal of Applied Animal Research. 45(1): 355-363.

Yadav, A. K., Singh, J. and Yadav, S. K. 2018. Characteristic features of Registered Indigenous Cattle breeds of India: A Review. Advances in Bioresearch. 9(1):01-15.

www.nbagr.res.in

ICAR-NBAGR Newsletter-2017. 


\section{How to cite this article:}

Savalia, K. B., A. R. Ahlawat, V. V. Gamit, S. S. Parikh and Verma, A. D. 2019. Recently Recognized Indigenous Cattle Breeds of India: A Review. Int.J.Curr.Microbiol.App.Sci. 8(12): 161-168. doi: https://doi.org/10.20546/ijcmas.2019.812.024 